\title{
THE CARDIOLIPIN-LECITHIN TEST FOR SYPHILIS
}

\author{
BY
}

\author{
R. P. JAYEWARDENE and T. VELAUDAPILLAI \\ Ceylon
}

Since the discovery of cardiolipin (Pangborn, 1941) serologists mainly in America have used it as the antigen for a simplified precipitation test for syphilis.

Cardiolipin is the lipid which, in combination with lecithin, gives the alcoholic extract of beef heart its antigenic properties. It is a complex phosphatidic acid with a molecular weight of 2195 and iodine number 120-125. It requires lecithin and cholesterol for antigenicity. It has not yet been synthesized. The cardiolipin-lecithin antigen may be adjusted to any desired sensitivity, within limits, merely by altering the ratio of cardiolipin and lecithin. Kline (1947) recommended a cardiolipin-lecithin ratio of $1: 9 \cdot 4$ and $1: 10.6$.

Our attempts to isolate and prepare the pure cardiolipin from beef heart were not successful. We have used as our antigen a cardiolipin-lecithin mixture of $1: 10$, standardized by Dr. Kline and supplied by the La Motte Chemical Company. The cardiolipin-lecithin (C.L.) test is now done as a routine on all samples sent to our laboratory.

\section{Procedure}

The serum is inactivated at $60^{\circ} \mathrm{C}$. for three minutes. The Wassermann, Kahn, and cardiolipin tests are done in parallel. The cardiolipin antigen is made by mixing :
(1) Distilled water, $0.85 \mathrm{ml}$.

(2) 1 per cent. alcoholic cholesterol, $1 \mathrm{ml}$.

(3) Cardiolipin antigen, $0.1 \mathrm{ml}$.

(4) 0.85 per cent. $\mathrm{NaCl}, 2.45 \mathrm{ml}$.

It is used ten minutes after mixing and discarded one hour later.

The test is done on large glass slides with wax rings $14 \mathrm{~mm}$. diameter.

Two drops of serum $0.05 \mathrm{ml}$. are put into each wax ring. One drop of antigen $0.008 \mathrm{ml}$. is added. The slides are rotated at 180 revolutions per minute for four minutes. The results are read with the naked eye. Known positive and negative sera are used as controls.

\section{Results}

The results are recorded as $+1,+2,+3,+4$, according to the size of the floccules, as is done in the Kahn test. The result of 2,776 blood sera are tabulated and analysed. All samples were obtained from the Venereal Diseases Clinic, General Hospital, Colombo, they have been divided into three groups :

(1) Early syphilis-first visit to the clinic and clinical diagnosis of syphilis.

(2) Syphilis under treatment.

(3) Non-syphilis.

TABLE I

CASES OF EARLY SYPHILIS

\begin{tabular}{|c|c|c|c|c|c|c|c|c|c|c|c|c|}
\hline \multirow{3}{*}{\multicolumn{2}{|c|}{ Test }} & \multicolumn{8}{|c|}{ Results } & \multirow{2}{*}{\multicolumn{2}{|c|}{$\begin{array}{c}\text { Total } \\
\text { positive }\end{array}$}} & \multirow{3}{*}{$\begin{array}{c}\text { Total } \\
\text { examined }\end{array}$} \\
\hline & & \multicolumn{2}{|c|}{0} & \multicolumn{2}{|c|}{+1} & \multicolumn{2}{|c|}{+2} & \multicolumn{2}{|c|}{$\begin{array}{c}+3 \\
\text { and over }\end{array}$} & & & \\
\hline & & No. & $\%$ & No. & $\%$ & No. & $\%$ & No. & $\%$ & No. & $\%$ & \\
\hline W.R. . . & . . & 65 & $18 \cdot 0$ & 32 & $9 \cdot 0$ & 260 & $72 \cdot 8$ & & & 292 & $81 \cdot 8$ & 357 \\
\hline Kahn & .. & 62 & $17 \cdot 4$ & 4 & $1 \cdot 1$ & 72 & $20 \cdot 2$ & 219 & $61 \cdot 3$ & 295 & $82 \cdot 6$ & 357 \\
\hline C.L. $\quad \ldots$ & .. & 42 & 11.8 & 16 & $4 \cdot 5$ & 120 & 33.6 & 179 & $50 \cdot 0$ & 315 & $88 \cdot 2$ & 357 \\
\hline
\end{tabular}


The $\chi^{2}$ test has been applied to these tables to see if the observed frequency distribution is different from that which is to be expected. The statistic $\chi^{2}$ has the value $31.4,192.9$, and 72.8 respectively, for the three tables. In each case the value of the statistic has a probability (P) of less than $1 / 1000$ that such a distribution would be found by chance.

From Table I we can conclude that in early cases of syphilis the W.R. test gives fewer double positive results than would be expected and more positive and negative results; the Kahn test gives more double positive and fewer single positive reactions ; and the C.L. test gives more double positive and fewer negative results than expected. This probably means the C.L. test is the most sensitive in detecting proved early cases of syphilis.

From Table II it can be concluded that in syphilitic cases under treatment the C.L. test gives strongly positive reactions for a longer period than the other two tests while the patient is being treated.

From Table III, non-syphilitic cases, we can conclude that the W.R. test gives fewer double positive results, and more single positive and negative, while the C.L. test gives more double positive and fewer negative results. This means that the C.L. test is more likely to give positive results in non-syphilitic cases than the others.

It appears therefore that the C.L. test is the more sensitive in indicating early syphilis, and that with its guidance the clinician is less likely to cease treatment too early. The C.L. test is also more likely to indicate as syphilitic definitely non-syphilitic cases, i.e., it is not completely specific for syphilis.

False Positive Results.-Cardiolipin tests have definite limitations, as false positive and false negative results may be obtained. In malaria the specificity of the test is much in evidence. In leprosy the false positive reactions have been found just as often as with other lipidal antigens (Rein, 1946 ; Stout, 1947). In infectious mononucleosis the cardiolipin tests are the first to become positive and the last to become negative (Rein, 1947).

We have examined the serums from 119 cases of yaws. In every case the cardiolipin test gave a plus two or over result. Other non-syphilitic conditions giving false positive results will be found when cardiolipin is more widely used.

TABLE II

CASES OF SYPHILIS UNDERGOING TREATMENT

\begin{tabular}{|c|c|c|c|c|c|c|c|c|c|c|c|c|c|}
\hline \multirow{3}{*}{\multicolumn{2}{|c|}{ Test }} & & \multicolumn{8}{|c|}{ Results } & \multirow{2}{*}{\multicolumn{2}{|c|}{$\begin{array}{c}\text { Total } \\
\text { positive }\end{array}$}} & \multirow{3}{*}{$\begin{array}{c}\text { Total } \\
\text { examined }\end{array}$} \\
\hline & & & \multicolumn{2}{|c|}{0} & \multicolumn{2}{|c|}{+1} & \multicolumn{2}{|c|}{+2} & \multicolumn{2}{|c|}{$\begin{array}{c}+3 \\
\text { and over }\end{array}$} & & & \\
\hline & & & No. & $\%$ & No. & $\%$ & No. & $\%$ & I No. & $\%$ & No. & $\%$ & \\
\hline W.R. & . & . & 731 & $55 \cdot 6$ & 147 & $11 \cdot 2$ & 437 & $33 \cdot 2$ & & & 584 & $44 \cdot 4$ & 1315 \\
\hline Kahn & . & & 630 & $46 \cdot 9$ & 55 & $4 \cdot 2$ & 297 & $22 \cdot 6$ & 333 & $25 \cdot 3$ & 685 & $52 \cdot 1$ & 1315 \\
\hline C.L. & . & $\ldots$ & 463 & $35 \cdot 2$ & 89 & $6 \cdot 8$ & 322 & $24 \cdot 5$ & 441 & $33 \cdot 5$ & 852 & $64 \cdot 8$ & 1315 \\
\hline
\end{tabular}

TABLE III

NON-SYPHILITIC CASES

\begin{tabular}{|c|c|c|c|c|c|c|c|c|c|c|c|c|c|}
\hline \multirow{3}{*}{\multicolumn{2}{|c|}{ Test }} & & \multicolumn{8}{|c|}{ Results } & \multirow{2}{*}{\multicolumn{2}{|c|}{$\begin{array}{c}\text { Total } \\
\text { positive }\end{array}$}} & \multirow{3}{*}{$\begin{array}{c}\text { Total } \\
\text { examined }\end{array}$} \\
\hline & & & \multicolumn{2}{|c|}{0} & \multicolumn{2}{|c|}{+1} & \multicolumn{2}{|c|}{+2} & \multicolumn{2}{|c|}{$\begin{array}{c}+3 \\
\text { and over }\end{array}$} & & & \\
\hline & & & No. & $\%$ & No. & $\%$ & No. & $\%$ & No. & $\%$ & No. & $\%$ & \\
\hline W.R. & . & . & 945 & $85 \cdot 0$ & 84 & $7 \cdot 6$ & 75 & $6 \cdot 8$ & & & 159 & $14 \cdot 4$ & 1104 \\
\hline Kahn & . & . & 989 & $89 \cdot 6$ & 18 & $1 \cdot 6$ & 72 & $6 \cdot 5$ & 25 & $2 \cdot 3$ & 115 & $10 \cdot 4$ & 1104 \\
\hline C.L. & . & $\ldots$ & 944 & $85 \cdot 5$ & 30 & $2 \cdot 7$ & 83 & $7 \cdot 5$ & 47 & $4 \cdot 3$ & 160 & $14 \cdot 5$ & 1104 \\
\hline
\end{tabular}




\section{Summary}

(1) The cardiolipin slide test was done on 2,776 sera together with parallel Wassermann and Kahn tests.

(2) The results are tabulated for comparison.

(3) A statistical analysis of these figures shows that the cardiolipin antigen is very sensitive.

(4) False positive results are obtained just as they are with other lipidal antigens.

Our thanks are due to Dr. L. B. E. Seneviratne, Director, Medical Research Institute, for his direction and help, and to Prof. H. Cullumbine of the University of Ceylon for his statistical analysis of our figures.

\section{REFERENCES}

Kline, B. S. (1947). Arch. Derm. Syph., Chicago, 55, 514.

Pangborn, M. (1941). Proc. Soc. exp. Biol. N.Y., 48, 484.

Rein, C. R., and Bossak, H. N. (1946). Amer. J. Syph., 30, 40.

, and Kent, J. F. (1947). J. Amer. med. Ass., 133, 1001.

Stout, G. W. (1947). Amer. J. Syph., 31, 314. 